\title{
CHANGING TRENDS OF ANTIBIOGRAM PROFILE IN PATIENTS WITH COMMUNITY ACQUIRED CHRONIC OTITIS MEDIA IN A TERTIARY CARE HOSPITAL
}

Bipasa Chakraborty ${ }^{1}$, Subhadip Dhara², Debasish Ghosh ${ }^{3}$, Kalidas Rit ${ }^{4}$, Anindita Sengupta ${ }^{5}$, Raja Ray ${ }^{6}$

\section{HOW TO CITE THIS ARTICLE:}

Bipasa Chakraborty, Subhadip Dhara, Debasish Ghosh, Kalidas Rit, Anindita Sengupta, Raja Ray. "Changing Trends of Antibiogram Profile in Patients with Community Acquired Chronic Otitis Media in a Tertiary Care Hospital". Journal of Evolution of Medical and Dental Sciences 2014; Vol. 3, Issue 45, September 18;

Page: $11000-11005$, DOI: $10.14260 /$ jemds/2014/3435

ABSTRACT: INTRODUCTION: Chronic otitis media (COM) is one among the commonest otological diseases encountered in otorhinolaryngological practice and attending ENT OPD especially among the lower socio-economic strata of society. AIMS: This study was carried out to know about the aerobic bacterial flora causing $\mathrm{COM}$ and in-vitro antibiotic susceptibility pattern in order to scientifically guide patient management instead of relying on empirical therapy alone. MATERIALS AND METHODS: This study included 100 patients of community acquired COM attending ENT OPD of a tertiary care level hospital. After proper sample collection by sterile aural swabs, they were immediately sent to the microbiology laboratory for processing by aerobic culture, isolation and identification following standard recommended methods and antibiotic susceptibility tests were done by Kirby-Bauer disc diffusion methods as per Clinical and Laboratory Standards Institute (CLSI) guidelines. RESULTS: Out of 100 cases of COM, microbiological culture yielded 101 bacterial isolates from 90 patients and 4 fungal isolates (3 isolates of Candida albicans and 1 isolate of Aspergillusfumigatus) from 4 patients. Polymicrobial infections were seen in $11.11 \%$ patients. In this study Staphylococcus aureus (31.68\%) was the commonest isolate followed by Pseudomonas aeruginosa (23.76\%). Other common bacterial isolates were E.coli, Klebsiellapneumoniae, coagulase negative Staphylococcus (CONS), Proteus mirabilis in descending order. Piperacillin-tazobactum was the most sensitive drug (85.45\%) among the gram-negative bacteria followed by meropenem (81.81\%), amikacin (76.36\%) and levofloxacin (74.54\%). Gram positive bacteria showed $100 \%$ sensitivity to vancomycin and $93.47 \%$ sensitivity to linezolid. For Methicillin resistant Staphylococcus aureus (MRSA) isolates ciprofloxacin, cotrimoxazole, tetracycline, linezolid and vancomycin were found to have good activity. CONCLUSION: This study suggests that the common etiological agents for community acquired COM were Staphylococcus aureus and Pseudomonas aeruginosa. Also correct choice of anti-bacterial agents by proper microbial sensitivity tests is necessary for effective therapy as the bacterial isolates are gradually becoming resistant to commonly prescribed antibiotics.

KEYWORDS: COM, bacteria, antibiotic susceptibility pattern, Staphylococcus aureus, Pseudomonas aeruginosa.

MESHTERMS: ((("Otitis Media"[Mesh]) AND "Bacteria"[Mesh]) AND "Anti-Bacterial Agents"[Mesh]) AND "Microbial Sensitivity Tests"[Majr].

INTRODUCTION: Chronic Otitis Media (COM) is chronic inflammation of middle ear affecting tympanic membrane, mucosa and middle ear structures resulting in long term sequelae and often 
permanent damages including atelectesis, dimer formation, perforation, tympanosclerosis, retraction pocket development or cholesteatoma.[1]

It results from long term Eustachian tube dysfunction with poorly aerated middle ear space, multiple bouts of acute otitis media, persistent middle ear infection or other chronic inflammatory stimuli.[1] Most common manifestation is ear discharge, perforation and hearing impairment.

Although surgery is the definitive treatment but there is always a place for conservative management for patients who don't give consent for surgery. Moreover in unsafe COM, any active infection should be controlled before surgery by proper antibiotics. Therefore a clear knowledge about the bacterial flora causing the infection and their antibiotic susceptibility pattern is very important for avoiding the hazards of injudicious use of anti-bacterial agents and prevention of emergence of resistant strains.

So this study was carried out to know about the aerobic bacterial flora causing COM and invitro antibiotic sensitivity pattern for better patient management.

MATERIALS AND METHODS: This prospective study was conducted in Otorhinolaryngology and Microbiology department of a tertiary care hospital in Kolkata from January 2013 to July 2013 and 100 clinically diagnosed cases of COM were included in this study.

Patients were excluded if having current febrile illness, any antibiotic use within 2 weeks, need for renal dialysis, recent ear surgery or in-situ grommet or tympanostomy tube, mastoid surgery in the preceding 12 months, any congenital ear anomaly, any hearing problems, obstructed middle ear (eg polyp), pregnancy and acute otitis media. The diagnosis of COM was based on presence of ear discharge for more than 6 weeks and on otoscopy the tympanic membrane showed permanent deformity like perforation, cholesteatoma and retraction. ${ }^{2]}$

Pus swabs collected were immediately sent to Microbiology department for aerobic culture and sensitivity. For isolation of bacteria, semi-quantitative culture from pus swabs were done on blood agar, Mac Conkey agar and chocolate agar media and were identified based on standard microbiological technique.[3] The antibiotic susceptibility testing (AST) of the clinical isolates to some routinely used antibacterial agents was done by Kirby Bauer disc diffusion method as per CLSI guidelines. ${ }^{[4]}$

Ampicillin, amikacin, gentamicin, ciprofloxacin, levofloxacin, amoxycillin-clavulanic acid, piperacillin-tazobactum, ceftriaxone, ceftazidime, cefepime and meropenem were tested against enterobacteriaceae. Amikacin, gentamicin, ciprofloxacin, levofloxacin, piperacillin-tazobactum, ceftazidime, cefepime, meropenem, were tested against Pseudomonas aeruginosa and Acinetobacter spp. Ampicillin, erythromycin, cefoxitin, ceftriaxone, ciprofloxacin, gentamicin, amoxycillin-clavulanic acid, cotrimoxazole, tetracycline, vancomycin and linezolid were tested against Staphylococcus aureus, coagulase negative Staphylococcus (CONS) and diphtheroids.

Ciprofloxacin, high level gentamicin, tetracycline, vancomycin and linezolid were tested for Enterococcus spp. Combination disc method using cefotaxime and ceftazidime alone and in combination with clavulanic acid was performed for detection of extended spectrum beta-lactamases (ESBL) among the members of enterobacteriaceae. Increase of $\geq 5 \mathrm{~mm}$ in zone of inhibition for either cefotaxime-clavulanic acid or ceftazidime-clavulanic acid disc compared to the cefotaxime or ceftazidime disc respectively was taken as confirmatory evidence of ESBL production. [5]

Modified Hodge test was carried out for detection of carbapenemase production. ${ }^{[5,6]}$ 
Development of a cloverleaf-shaped zone of inhibition due to carbapenemase production by the test strain was considered positive. EDTA disc synergy test was done using meropenem for detection of metallo-beta-lactamase (MBL) with the meropenem resistant strains. ${ }^{[6]}$ After 24 hours of incubation at $37^{\circ} \mathrm{C}$, an increase of $\geq 7 \mathrm{~mm}$ in the zone diameter of EDTA-containing meropenem disk compared to meropenem disk alone was considered to be a positive test for the presence of MBL in meropenem resistant strains. Detection of MRSA was done by using $30 \mu \mathrm{g}$ disc of cefoxitin as per Clinical Laboratory Standard Institute (CLSI) guidelines. ${ }^{[5]}$

Among the gram negative bacilli causing COM, those producing ESBL or MBL and among the gram positive cocci, MRSA and Enterococcus spp, with resistance to two or more antibiotics, often including, but not limited to vancomycinare defined as multidrug resistant (MDR) pathogens. ${ }^{[7]}$

RESULTS: Out of the 100 consecutive cases of COM included in this study $60 \%$ patients were males and were uniformly seen in all age groups. So the median age of patients in this study was 34.56 years.Out of 100 cases of COM, microbiological culture yielded 101 bacterial isolates from 90 patients and 4 fungal isolates (3 isolates of Candida albicans and 1 isolate of Aspergillusfumigatus) from 4 patients. The microbiological profile of aerobic bacterial isolates is shown in graph-1.

The most common bacterial agents isolated were Staphylococcus aureus (31.68\%) followed by Pseudomonas aeruginosa (23.76\%). Polymicrobial infections were seen in $10(11.11 \%)$ patients. The antibiotic sensitivity profiles of various etiological agents of COM are summarized in Table- 1 . Among the enterobacteriaceae, 28.57\% were ESBL producers and $10.71 \%$ were MBL producers. $34.37 \%$ of Staphylococcus aureus were MRSA and 40\% of Enterococcus spp were found to be MDR.

DISCUSSION: The incidence of COM is high in developing countries because of poor socio-economic standards, poor nutrition and lack of health education. ${ }^{[8]}$ The wide spread and injudicious use of antibiotics has precipitated the emergence of resistant strains usually not responding to commonly prescribed medicines.

This study showed predominance of gram-negative bacteria (54.45\%) as also seen in other studies by Kumar $\mathrm{H}$ et al.[8]Although most of the studies reported Pseudomonas as most common isolate,[8-11] but in our studyStaphylococcus aureus $(n=32,31.68 \%)$ was the most common isolate followed by Pseudomonas aeruginosa $(n=24,23.76 \%)$ as also reported by Prakash $M$ et al.[12] Other isolates were E. coli, Klebsiellapneumoniae, CONS, Proteus mirabilis, Enterococcus spp, Acinetobacter spp. diphtheroids and Citrobacterfruendi.

Most common isolate Staphylococcus aureus were found to be $100 \%$ sensitive to vancomycin and $94 \%$ sensitive to linezolid similar to other studies. ${ }^{[8-10]}$ Sensitivity of gram positive bacteria for tetracycline was $81.25 \%$. Pseudomonas isolates were found to be $92 \%$ sensitive for piperacillintazobactum, followed by meropenem (87.5\%) and levofloxacin (87.5\%). Sensitivity of Pseudomonas for amikacin was $69 \%$ and ceftazidime $60 \%$ in our study but results of Mansoor et al.[13]

Showed much higher sensitivity of $>95 \%$ for amikacin and $89 \%$ for ceftazidime. Overall sensitivity for amikacin was $76 \%$ and gentamicin was $61 \%$. Around $82 \%$ isolates showed resistance to ampicillin, once most commonly used drugs, hence alerting the clinicians to use this antibiotic only after doing AST. Even amoxicillin-clavulanic acid combination showed 50\% resistance contrary to other studies which showed greater sensitivity.[9] Overall this study has reported greater resistance pattern among the bacterial isolates than other studies. ${ }^{[8-12]}$ 
Among the flouroquinolones, sensitivity of levofloxacin (75\%) was much greater than ciprofloxacin (67.32\%). Among the cephalosporins, ceftazidime was most active against $80 \%$ of Pseudomonas and with overall sensitivity for $71 \%$ isolates. So from AST performed in this study, for ESBL producers, piperacillin-tazobactum, meropenem, amikacin and levofloxacin can be the preferred antibiotic while for MBL producersamikacin and levofloxacin were good. For Methicillin resistant Staphylococcus aureus (MRSA) isolates ciprofloxacin, cotrimoxazole, tetracycline, linezolid and vancomycin were found to be effective.

Thus clinician routinely prescribing anti-bacterial agents for $\mathrm{COM}$, without performing antibiotic susceptibility tests is totally unjustified. Therefore a clear knowledge about the bacterial flora causing the infection and their susceptibility pattern is very important. The isolates are gradually becoming more resistant and the bacteriological as well as susceptibility pattern is changing from time to time requiring continuous surveillance of AST for effective management of COM.

\section{REFERENCES:}

1. Gopen Q. Pathology and clinical course of the inflammatory diseases of the middle ear. In: Gulya AJ, Minor LB, Poe DS, editors. Glasscock-Shambaugh Surgery of the Ear.Sixth edition ed. People's Medical Publishing House-USA; 2010: 427.

2. Bluestone CD, Gates GA, Klein JO, Lim OJ, Mogi G, Ogra PL et al. Definitions, terminology and classification of otitis media. Annals of Otology, Rhinology and Laryngology 2002; 11 (1): 8- 18.

3. Collee JG, Miles RS, Watt B. Tests for the identification of bacteria. In: Collee JG, Marmion BP, Fraser AG, Simmons A, editors. Mackie and McCartney's Practical Medical Microbiology. 14th edition. Churchill Livingstone New York; 1996: 131-49.

4. CLSI. Performance standards for antimicrobial disk susceptibility tests. Approved standard, 9th ed. CLSI document M2-A9. Wayne, PA: Clinical and Laboratory Standards Institute; 2006.

5. CLSI. Performance standards for antimicrobial susceptibility testing; Twenty-fourth informational supplement. CLSI document M100-S-24. Wayne, PA: Clinical and Laboratory Standards Institute; 2014.

6. Yong D, Lee K, Yum JH, Shin HB, Rossolini GM, Chong Y. Imipenem EDTA disk method for differentiation of Metallobetalactamase producing clinical isolates of Pseudomonas spp. and Acinetobacter spp. J ClinMicrobiol 2002;40:3798-801.

7. Huycke MM, Sahm DF, Gilmore MS. Multiple-Drug Resistant Enterococci: The Nature of the Problem and an Agenda for the Future. Emerging Infectious Diseases 1998; 4(2):239-46

8. Kumar H, Seth S. Bacterial and Fungal Study of 100 Cases of Chronic Suppurative Otitis Media. Journal of Clinical and Diagnostic Research 2011; 5(6): 1224-27.

9. Kumar S, Sharma R, Saxena A, Pandey A, Gautam P, Taneja V. Bacterial flora of infected unsafe CSOM. Indian Journal of Otology 2012; 18(4):208-11.

10. Sattar A, Alamgir A, Hussain Z, Sarfraz S, Nasir J, Alam B. Bacterial Spectrum and Their Sensitivity Pattern in Patients of Chronic Suppurative Otitis Media. Journal of the College of Physicians and Surgeons Pakistan 2012, Vol. 22 (2): 128-29.

11. Shetty AK, Shetty A. Aerobic bacteriological profile and their antibiotic susceptibility in Chronic Suppurative Otitis Media in patients from Mangalore, Karnataka State. J AcadClinMicrobiol 2014;16:3-7. 
12. Prakash M, Lakshmi K, Anuradha S, Swathi GN. Bacteriological profile and their antibiotic susceptibility pattern of cases of chronic suppurative otitis media.Asian J Pharm Clin Res 2013; 6(3): 210-12.

13. Mansoor T, Musani MA, Khalid G, Kamal M. Pseudomonas aeruginosain chronic suppurative otitis media: sensitivityspectrum against various antibiotics in Karachi. J Ayub Med Coll Abbottabad. 2009; 21:120-3.

\begin{tabular}{|c|c|c|c|c|c|c|c|c|c|c|c|}
\hline \multirow{2}{*}{$\begin{array}{l}\text { Etiological agents } \\
\text { (no. of isolates) }\end{array}$} & \multicolumn{11}{|c|}{ Antibiotic sensitivity pattern in percentage \% (no. of isolates) } \\
\hline & AMP & AMK & GEN & CIP & LEV & AMC & PTZ & CTR & CAZ & CPM & MER \\
\hline $\begin{array}{l}\text { Pseudomonas } \\
\text { aeruginosa (24) }\end{array}$ & --- & $\begin{array}{l}91.66 \\
(22)\end{array}$ & $\begin{array}{l}79.16 \\
(19)\end{array}$ & $\begin{array}{c}83.33 \\
(20)\end{array}$ & $\begin{array}{l}87.50 \\
(21)\end{array}$ & --- & $\begin{array}{l}91.66 \\
(22)\end{array}$ & $\ldots$ & $\begin{array}{c}79.16 \\
(19)\end{array}$ & $\begin{array}{l}75.0 \\
(18)\end{array}$ & $\begin{array}{l}87.5 \\
(21)\end{array}$ \\
\hline $\begin{array}{l}\text { Escherichia } \\
\text { coli (14) }\end{array}$ & $\begin{array}{c}14.28 \\
(2)\end{array}$ & $\begin{array}{c}57.14 \\
(8)\end{array}$ & $\begin{array}{c}42.85 \\
(6)\end{array}$ & $\begin{array}{c}42.85 \\
(6)\end{array}$ & $\begin{array}{c}50.0 \\
(7)\end{array}$ & $\begin{array}{c}28.57 \\
(4)\end{array}$ & $\begin{array}{c}87.71 \\
(12)\end{array}$ & $\begin{array}{c}50.0 \\
(7)\end{array}$ & $\begin{array}{c}57.14 \\
(8)\end{array}$ & $\begin{array}{c}57.14 \\
(8)\end{array}$ & $\begin{array}{r}78.57 \\
(11)\end{array}$ \\
\hline $\begin{array}{l}\text { Klebsiella } \\
\text { pneumoniae (7) }\end{array}$ & $\begin{array}{c}14.28 \\
(1)\end{array}$ & $\begin{array}{c}71.42 \\
(5)\end{array}$ & $\begin{array}{c}71.42 \\
(5)\end{array}$ & $\begin{array}{c}57.14 \\
(4)\end{array}$ & $\begin{array}{c}57.14 \\
(4)\end{array}$ & $\begin{array}{c}42.85 \\
(3)\end{array}$ & $\begin{array}{c}71.42 \\
(5)\end{array}$ & $\begin{array}{c}42.85 \\
(3)\end{array}$ & $\begin{array}{c}57.14 \\
(4)\end{array}$ & $\begin{array}{c}57.14 \\
(4)\end{array}$ & $\begin{array}{c}71.42 \\
(5)\end{array}$ \\
\hline $\begin{array}{l}\text { Proteus } \\
\text { mirabilis (5) }\end{array}$ & $\begin{array}{c}20.0 \\
(1)\end{array}$ & $\begin{array}{c}80.0 \\
(4)\end{array}$ & $\begin{array}{c}60.0 \\
(3)\end{array}$ & $\begin{array}{c}80.0 \\
(4)\end{array}$ & $\begin{array}{c}80.0 \\
(4)\end{array}$ & $\begin{array}{c}40.0 \\
(2)\end{array}$ & $\begin{array}{c}80.0 \\
(4)\end{array}$ & $\begin{array}{c}80.0 \\
(4)\end{array}$ & $\begin{array}{c}80.0 \\
(4)\end{array}$ & $\begin{array}{c}80.0 \\
(4)\end{array}$ & $\begin{array}{c}80.0 \\
(4)\end{array}$ \\
\hline $\begin{array}{l}\text { Acinetobacter } \\
\text { spp (3) }\end{array}$ & --- & $\begin{array}{c}33.33 \\
(1)\end{array}$ & $\begin{array}{c}33.33 \\
(1)\end{array}$ & $\begin{array}{c}66.66 \\
(2)\end{array}$ & $\begin{array}{l}100 \\
(3)\end{array}$ & $-\cdots$ & $\begin{array}{c}66.66 \\
(2)\end{array}$ & ---- & $\begin{array}{c}66.66 \\
(2)\end{array}$ & $\begin{array}{c}33.33 \\
(1)\end{array}$ & $\begin{array}{c}66.66 \\
(2)\end{array}$ \\
\hline $\begin{array}{l}\text { Citrobacter } \\
\text { freundii (2) }\end{array}$ & $\begin{array}{c}0.00 \\
(0)\end{array}$ & $\begin{array}{l}100 \\
(2)\end{array}$ & $\begin{array}{l}100 \\
(2) \\
\end{array}$ & $\begin{array}{l}100 \\
(2) \\
\end{array}$ & $\begin{array}{l}100 \\
(2) \\
\end{array}$ & $\begin{array}{c}0.00 \\
(0) \\
\end{array}$ & $\begin{array}{l}100 \\
(2)\end{array}$ & $\begin{array}{c}50.0 \\
(1)\end{array}$ & $\begin{array}{l}100 \\
(2)\end{array}$ & $\begin{array}{c}50.0 \\
(1) \\
\end{array}$ & $\begin{array}{l}100 \\
(2) \\
\end{array}$ \\
\hline & AMP & ERY & CXN & CTR & CIP & GEN & AMC & COT & TET & VAN & LZ \\
\hline $\begin{array}{l}\text { Staphylococcus aureus } \\
\text { (32) MRSA(11) }\end{array}$ & $\begin{array}{c}18.75 \\
(6)\end{array}$ & $\begin{array}{c}59.37 \\
(19)\end{array}$ & $\begin{array}{c}65.62 \\
(21)\end{array}$ & $\begin{array}{l}62.5 \\
(20)\end{array}$ & $\begin{array}{l}68.75 \\
(22)\end{array}$ & $\begin{array}{c}56.25 \\
(18)\end{array}$ & $\begin{array}{l}62.50 \\
(20)\end{array}$ & $\begin{array}{l}75.00 \\
(24)\end{array}$ & $\begin{array}{l}81.25 \\
(26)\end{array}$ & $\begin{array}{l}100 \\
(32)\end{array}$ & $\begin{array}{r}93.75 \\
(30)\end{array}$ \\
\hline CONS (6) & $\begin{array}{c}16.66 \\
(1)\end{array}$ & $\begin{array}{c}66.66 \\
(4)\end{array}$ & $\begin{array}{l}100 \\
(6)\end{array}$ & $\begin{array}{c}83.33 \\
(5)\end{array}$ & $\begin{array}{c}50.0 \\
(3)\end{array}$ & $\begin{array}{c}33.33 \\
(2)\end{array}$ & $\begin{array}{c}66.66 \\
(4)\end{array}$ & $\begin{array}{c}83.33 \\
(5)\end{array}$ & $\begin{array}{l}100 \\
(6)\end{array}$ & $\begin{array}{l}100 \\
(6)\end{array}$ & $\begin{array}{l}100 \\
(6)\end{array}$ \\
\hline $\begin{array}{l}\text { Enterococcus } \\
\operatorname{spp}(5)\end{array}$ & --- & ---- & ---- & --- & $\begin{array}{c}60.0 \\
(3)\end{array}$ & $\begin{array}{c}80.0 \\
(4) \\
(\mathrm{HLG})\end{array}$ & ---- & --- & $\begin{array}{c}60.0 \\
(3)\end{array}$ & $\begin{array}{l}100 \\
(5)\end{array}$ & $\begin{array}{c}80.0 \\
(4)\end{array}$ \\
\hline Diphtheroids (3) & $\begin{array}{c}33.33 \\
(1)\end{array}$ & $66.66(2)$ & --- & $\begin{array}{c}66.66 \\
(2)\end{array}$ & $\begin{array}{c}66.66 \\
(2)\end{array}$ & $\begin{array}{l}100 \\
(3)\end{array}$ & $\begin{array}{c}66.66 \\
(2)\end{array}$ & $\begin{array}{c}66.66 \\
(2)\end{array}$ & -- & $\begin{array}{l}100 \\
(3)\end{array}$ & $\begin{array}{l}100 \\
(3)\end{array}$ \\
\hline
\end{tabular}

Table 1: Antibiotic Sensitivity profile of the etiological agents of COM

COM- Chronic otitis media, AMP-ampicillin, AMK-amikacin, GEN-gentamicin, CIPciprofloxacin, LEV- levofloxacin, AMC- amoxycillin-clavulanic acid, PTZ-piperacillin-tazobactum, CTRceftriaxone, CAZ-ceftazidime, CPM- cefepime, MER- meropenem, ERY-erythromycin, CXN-cefoxitin, COT-cotrimoxazole, TET-tetracycline, VAN-vancomycin, LZ-linezolid, MRSA-Methicillin resistant Staphylococcus aureus, HLG-High level gentamicin. 


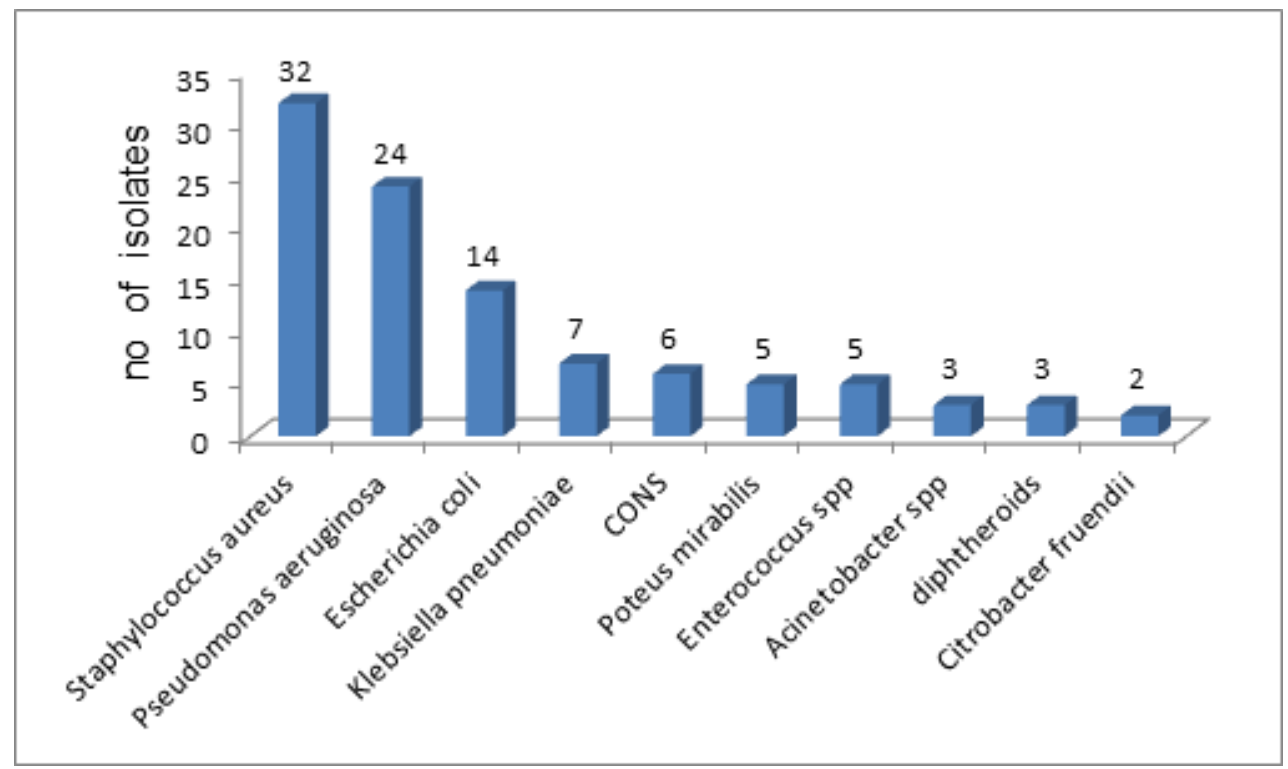

Graph 1: Microbiological profile of aerobic bacterial isolates

\section{AUTHORS:}

1. Bipasa Chakraborty

2. Subhadip Dhara

3. Debasish Ghosh

4. Kalidas Rit

5. Anindita Sengupta

6. Raja Ray

\section{PARTICULARS OF CONTRIBUTORS:}

1. Consultant, Department of Microbiology, Ashok Laboratory Clinical testing Centre Pvt. Ltd, Jodhpur Park, Kolkata.

2. Senior Resident, Department of Otorhinolaryngology, Institute of PostGraduate Medical Education \& Research, AJC Bose Road, Kolkata.

3. RMO Cum Clinical Tutor, Department of Otorhinolaryngology, Institute of PostGraduate Medical Education \& Research, AJC Bose Road, Kolkata.

4. Assistant Professor, Department of Microbiology, Institute of Post Graduate Medical Education \& Research, AJC Bose Road, Kolkata.
5. Senior Resident, Department of Otorhinolaryngology, Institute of Post Graduate Medical Education \& Research, AJC Bose Road, Kolkata.

6. Professor, Department of Microbiology, Institute of Post Graduate Medical Education \& Research, AJC Bose Road, Kolkata.

\section{NAME ADDRESS EMAIL ID OF THE CORRESPONDING AUTHOR:}

Dr. Bipasa Chakraborty,

Flat -1B, Anandam Apartments, 107, Garfa Main Road,

Kolkata-700075.

Email: bipasa_doc@yahoo.co.in

Date of Submission: 05/09/2014. Date of Peer Review: 06/09/2014. Date of Acceptance: 11/09/2014. Date of Publishing: 17/09/2014. 